\title{
Persuasive Object Oriented Programming Lab Assignment Framework
}

\author{
Elly Johana Johan \\ Fakulti Sains Komputer dan Matematik, \\ Universiti Teknologi MARA Perlis, 02600 \\ Arau, Perlis, Malaysia
}

\begin{abstract}
This paper presents an example of how principles of persuasive technology can be adopted into educational Object Oriented Programming (OOP) lab assignments and integrated with incremental, iterative and guided approaches which are expected to motivate students in learning OOP. This form of assignment makes students stay and commit in the task. An easy start helps the students to initiate working early, and those who do so are much more likely to complete the assignment they have already in progress. They have a clearer interpretation of what they are doing so it is easy to start and not 'freeze' at the assignment. An early start to the assignment looks to be a powerful indicator for passing the assignment and achieve the learning outcomes. As conclusion, this study has shown the effectiveness of the persuasive technology principles and the integrated of incremental, iterative and guided approaches to improving OOP lab assignments.
\end{abstract}

\section{Introduction}

Eckerdal and Thune reported many students point out the concepts of object and class are difficult to learn although they make an effort to understand them [1]. Majority of students find themselves in dilemma while solving programming or even OOP lab assignment and thus resulting in poor grade. The traditional ways of OOP lab assignments leave students clueless as to how they should tackle the assignment. It can be tricky especially if a student is learning a new programming concept.

Paradigms of teaching clarify how education should be conceptualized, how assorted tools or techniques can be used in order to improve the teaching approach. Persuasive technology can motivate people to initiate a learning process, to stay on task, and then to review material as needed [7].

\section{Persuasive Technology}

According to B.J. Fogg, director of the Persuasive Technology Lab at Stanford University, persuasive technology refers to any interactive computing system designed to change people's

\author{
Sufian Idris, Marini Abu Bakar and \\ Muriati Mukhtar \\ Fakulti Teknologi dan Sains Maklumat, \\ Universiti Kebangsaan Malaysia,43600, \\ Bangi, Selangor, Malaysia
}

attitude or behavior [3]. In most cases, computers as persuasive device influence attitude and behaviour changes by escalating a person's capability or making something easier to do [8].

There is a diversity of specialized categories created by researchers and practitioners in the field of persuasive technology that is general in the beginning. Theorists have varied in how they individuate these influence principles: Fogg explains 43 principles of persuasive technology that can be used to change people's attitude in commercial and non-commercial domains, Cialdini develops six principles at length, Kellermann and Cole gather 64 groups from several taxonomies and OinasKukkonen and Harjumaa listing 28 design principles for persuasive system content and functionality [2] [3] [4] [6] [10]. These different counts result from differing levels of exhaustiveness, exclusivity, emphasis, and granularity [6].

In the last ten years, persuasion has been investigated in two apparently distinct lines of research: captology and teaching as persuasion. B.J. Fogg has coined the phrase "Captology" which he derived as a partial acronym for Computers $\underline{A} s$ $\underline{P}$ ersuasive $\underline{T}$ echnologies (CAPT-ology), for this area of study [3]. Captology is associated to the positive, ethical applications of persuasive technologies, focusing on the design, research, and analysis of interactive computing products created for the purpose of changing people's attitudes or behaviours [3]. While, teaching as persuasion is connected on the use of persuasion as a pedagogical approach to teaching and on creating educational software that motivate students to obtain new knowledge and skills [9].

\section{Research Description}

One of the methods to assess students' comprehension in learning OOP is through programming assignments which are normally conducted during lab sessions. In spite of many examples and exercises discussed during the lecture coupled with readily available references from textbooks and web portals, students continue to face problems when writing and understanding programming codes individually. This is quite observable for average and weak category of students. 
Traditionally, the OOP lab assignments given to students are in the form of problem-based questions. The problem is usually described in textbooks without any guidance to help students solve it. They often have difficulty completing OOP lab assignments due to difficulty to completely understand the material presented during lectures, lack of revision after lecture and less practice of programming exercise before the lab session. Even so, they are able to solve simple and straightforward problems but have difficulty in completing programming assignments for advanced topics. They have potential but need guidance from the lecturers and supporting materials related to the problem. Furthermore, this is a course in the second year that requires basic programming skills from the previous course. Problems faced by students are challenging the ability of lecturers to produce OOP lab assignments that appeal especially to average category students. Based on observations of student enrolment each semester, the majority are from this category.

Persuasive technology provides a broad platform in the use of hardware and techniques to create a more conducive learning environment in enhancing motivation and students interest in their study. Inspired from captology and teaching as persuasion the main objective of this action study was to develop a framework of OOP lab assignments by integrating the incremental, iterative and guided approaches through the adoption of persuasive technology which can be used as a guide for designing persuasive OOP lab assignments that can benefit and appeal especially to average category of students in learning OOP [3] [9].

\section{Conceptual Framework}

The conceptual framework of OOP lab assignment is projected through the categories of persuasive system principles suggested by OinasKukkonen and Harjumaa consisting of the primary task, dialogue, system credibility and social support categories [4]. There are 10 principles according to their respective categories are adopted in developing this framework. Then, Elaboration Likelihood Model (ELM) of persuasion is employed to design OOP lab assignment which divided into two parts; content and context. Figure 1. below, illustrate the conceptual framework of persuasive OOP lab assignment.

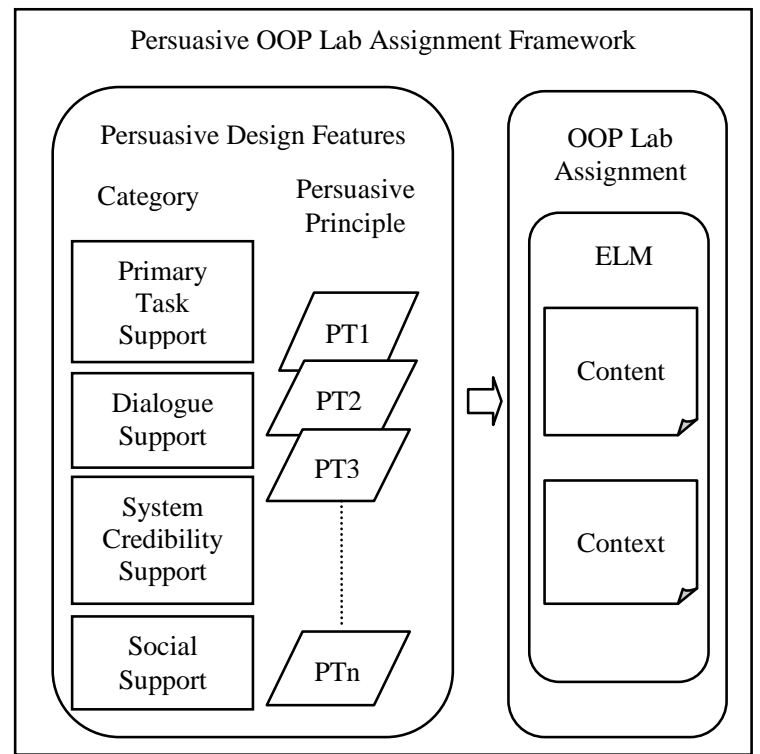

Figure 1. Conceptual framework of persuasive OOP lab assignment

\subsection{Primary Task Support}

The design principles in primary task support category provide an environment to the user to perform key tasks. The design principles in this category are reduction, tunneling, tailoring, personalization, self-monitoring, simulation, and rehearsal. Table 1. shows a description of five principles adopted within this category in developing the persuasive OOP lab assignment framework.

Table 1. Primary Task Support

\begin{tabular}{|c|c|}
\hline $\begin{array}{l}\text { Assignment } \\
\text { Requirement }\end{array}$ & $\begin{array}{c}\text { Persuasive Technology } \\
\text { Principles }\end{array}$ \\
\hline $\begin{array}{l}\text { 1. An assignment } \\
\text { should provide } \\
\text { tailored } \\
\text { information for } \\
\text { its user groups. }\end{array}$ & $\begin{array}{l}\text { Tailoring (PTTR) } \\
\text { Information provided by } \\
\text { the assignment will be } \\
\text { more persuasive if it is } \\
\text { tailored to the potential } \\
\text { needs, interests, } \\
\text { personality, usage context, } \\
\text { or other factors relevant to } \\
\text { a user group. }\end{array}$ \\
\hline $\begin{array}{l}\text { 2. An assignment } \\
\text { should reduce } \\
\text { effort that } \\
\text { students expend } \\
\text { with regard to } \\
\text { performing their } \\
\text { target behaviour. }\end{array}$ & 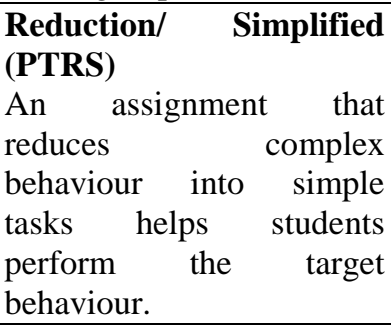 \\
\hline $\begin{array}{l}\text { 3. An assignment } \\
\text { should guide } \\
\text { students in the } \\
\text { attitude change } \\
\text { process } \\
\text { providing means }\end{array}$ & $\begin{array}{l}\text { Tunneling (PTTU) } \\
\text { Using the assignment to } \\
\text { guide students through a } \\
\text { process or experience } \\
\text { provides opportunities to } \\
\text { persuade along the way. }\end{array}$ \\
\hline
\end{tabular}




\begin{tabular}{|l|l|}
\hline $\begin{array}{l}\text { for action that } \\
\text { brings them } \\
\text { closer to the } \\
\text { target behaviour. }\end{array}$ \\
\hline $\begin{array}{l}\text { 4. An assignment } \\
\text { should provide } \\
\text { means folf-monitoring (PTSM) } \\
\text { students to track } \\
\text { their performance }\end{array}$ & $\begin{array}{l}\text { performance or status } \\
\text { supports the student in } \\
\text { or status. }\end{array}$ \\
\hline $\begin{array}{l}\text { 5. An assignment } \\
\text { should provide } \\
\text { simulations by }\end{array}$ & $\begin{array}{l}\text { Simulation / Cause and } \\
\text { Effect (PTCE) } \\
\text { enable students to } \\
\text { observe } \\
\text { immediately the } \\
\text { link between } \\
\text { students to change their } \\
\text { attitudes or behaviours by } \\
\text { enabling them to observe } \\
\text { immediately the link } \\
\text { between cause and effect. }\end{array}$ \\
\hline
\end{tabular}

\subsection{Dialogue Support}

The design principles in dialogue support category helps users keep moving towards their objective include praise, rewards, reminders, suggestion, similarity, liking, cooperation and social role. Three principles liking, similarity and suggestion are adopted in developing this framework as explain in Table 2.

Table 2. Dialogue Support

\begin{tabular}{|l|l|}
\hline $\begin{array}{c}\text { Assignment } \\
\text { Requirement }\end{array}$ & \multicolumn{1}{|c|}{$\begin{array}{c}\text { Persuasive Technology } \\
\text { Principles }\end{array}$} \\
\hline $\begin{array}{l}\text { 1. An assignment } \\
\text { should have a } \\
\text { look and feel that } \\
\text { appeals to } \\
\text { students. }\end{array}$ & $\begin{array}{l}\text { Liking (PTLK) assignment that is } \\
\text { visually attractive for } \\
\text { students is likely to be } \\
\text { more persuasive. }\end{array}$ \\
\hline $\begin{array}{l}\text { 2. An assignment } \\
\text { should suggest } \\
\text { that students } \\
\text { carry out } \\
\text { behaviours during } \\
\text { the process. }\end{array}$ & $\begin{array}{l}\text { Suggestion (PTSG) assignment offering } \\
\text { fitting suggestions will } \\
\text { have greater persuasive } \\
\text { powers. }\end{array}$ \\
\hline $\begin{array}{l}\text { 3. An assignment } \\
\text { should imitate } \\
\text { students in some } \\
\text { specific way. }\end{array}$ & $\begin{array}{l}\text { Similarity (PTSS) } \\
\text { Students are more readily } \\
\text { persuaded through systems } \\
\text { that remind them of } \\
\text { themselves in some } \\
\text { meaningful way. }\end{array}$ \\
\hline
\end{tabular}

\subsection{System Credibility Support}

The design principles in system credibility support category explain the design of an OOP lab assignments so that it is more credible and thus more persuasive. The principles in that belong into this category are trustworthiness, expertise, surface credibility, real-world feel, authority, third-party endorsements, and verifiability. Table 3. describes the expertise principles adopted of this category.

Table 3. System Credibility Support

\begin{tabular}{|l|l|}
\hline $\begin{array}{c}\text { Assignment } \\
\text { Requirement }\end{array}$ & \multicolumn{1}{c|}{$\begin{array}{c}\text { Persuasive Technology } \\
\text { Principles }\end{array}$} \\
\hline $\begin{array}{l}\text { 1. An assignment } \\
\text { should provide } \\
\text { information } \\
\text { showing } \\
\text { knowledge, } \\
\text { experience, and } \\
\text { competence. }\end{array}$ & $\begin{array}{l}\text { Expertise (PTEX) } \\
\text { with current, relevant, well } \\
\text { coordinated information } \\
\text { and viewed as } \\
\text { incorporating expertise } \\
\text { will has a greater potential } \\
\text { to persuade. }\end{array}$ \\
\hline
\end{tabular}

\subsection{Social Support}

The design principles in the social support category describe how to design the system so that it motivates users by leveraging social influence. The design principles that belong into this category are social facilitation, social comparison, normative influence, social learning, cooperation, competition, and recognition. Table 4. explicate the cooperation principles adopted of this category.

Table 4. Social Support

\begin{tabular}{|c|l|}
\hline $\begin{array}{c}\text { Assignment } \\
\text { Requirement }\end{array}$ & \multicolumn{1}{|c|}{$\begin{array}{c}\text { Persuasive Technology } \\
\text { Principles }\end{array}$} \\
\hline $\begin{array}{c}\text { 1. An assignment } \\
\text { should provide }\end{array}$ & $\begin{array}{l}\text { Cooperation ( PTCO) } \\
\text { An assignment can } \\
\text { means for co- } \\
\text { operation. }\end{array}$ \\
& $\begin{array}{l}\text { a target attitude or students to adopt } \\
\text { behaviour by leveraging } \\
\text { human beings natural } \\
\text { drive to cooperate. }\end{array}$ \\
\hline
\end{tabular}

\subsection{Elaboration Likelihood Model (ELM)}

According to the ELM there is a division between two routes leading to persuasion; the central route and the peripheral route [12]. Petty and Cacioppo characterize information quality is leading the central route, whereas context is dominant in the peripheral route [11]. Referring to the conceptual in framework in Figure 1, 'content' was defined as concepts or messages in which the OOP lab assignments are trying to deliver to the targeted users (average category of students). For that reason, the content was the information quality of the central route. While "context" represents the peripheral route, as it was defined as the approaches that can be used to explain the content. Accordingly, the framework was designed using incremental, iterative and guided 
approaches in order to make the OOP lab assignments more persuasive.

Motivation formed through high elaboration, the central route is more persistent ultimately, more resistant to change, and more predictive of behavior compared to the change from low elaboration, the peripheral route [11]. Motivation under the peripheral route is an instant outcome. The immediate outcome was related to the instant cause and effects of persuasive OOP lab assignment towards motivation and commitments level especially during the lab session conducted for two hours per session. Through the central route which is more persistent over time, students were able to capture the significant concepts presented in the assignments during the learning process takes place. According to Mintz and Aagaard persuasive technology tools such as tailoring, tunnelling and reduction have major overlap with the metaphor of "scaffolding", focusing on offering support to the learner to allow them to achieve a higher outcome than they would do independently [5]. In accordance with the opinion expressed by Mintz and Aagaard, this framework was also developed as a scaffolding to provide step-by-step persuasive guidance iteratively exclusive to targeted groups, average category of students to complete the lab assignments given [5]. It is believed that they will go through a transformation process in which they can become independent and be able to deal with traditional lab assignments well in line with the programming skills developed throughout the learning process. By means of it, the motivation levels produced in both routes are supposed to be significant for this study.

\section{OOP Lab Assignment Framework}

Figure 2. shows the details of the framework used to design persuasive OOP lab assignments.

1. Introduction
a. Title
b. Focused OO Concepts
c. Background Information

2. What is this exercise about...

3. What should I know to be able to do this exercise.

4. What will I learn from this programming exercise...

5. What resources are provided..

a. Video file that describes what needs to be generated for each stage.

b. The sample file that can be executed without program code.

c. Working file that contains some specific program code that will be used to write a complete program. It includes a collection of classes available to write a complete program. d. Class documentation containing useful information to be used as reference for writing a complete program.

6. What do I need to do..

a. Task description

b. At the end of this stage, you should have produced a program which...

c. What is this stage about...

d. Procedure

i. Reinforcement Question

Figure 2. Persuasive OOP Lab Assignment Framework

Each section of the assignment was an adoption of persuasive technology principles as specified in the development of the conceptual framework before. The final section of "What do I need to do" was presented using guided, incremental (stages) and iterative approaches. Each stage was the expansion of the previous stage until the complete program is developed to solve the problem described in the section "What is this exercise about ...". Table 5. shows the correlation of each section with persuasive principles that have been adopted.

Table 5. Assignment Section and Persuasive Principles

\begin{tabular}{|c|c|c|}
\hline Section & Principles & Description \\
\hline Introduction & Expertise & $\begin{array}{l}\text { The introduction } \\
\text { gives an overview } \\
\text { of the assignment } \\
\text { and giving ideas } \\
\text { and initial } \\
\text { information that } \\
\text { students should } \\
\text { know to perform } \\
\text { the task. }\end{array}$ \\
\hline \multicolumn{3}{|c|}{ Sub section of Introduction } \\
\hline Title & Expertise & $\begin{array}{l}\text { "Title" of the lab } \\
\text { assignment help } \\
\text { students to get a } \\
\text { comprehensive } \\
\text { idea about the } \\
\text { assignment. }\end{array}$ \\
\hline $\begin{array}{l}\text { Focused OO } \\
\text { Concepts }\end{array}$ & Tunneling & $\begin{array}{l}\text { "Focused OO } \\
\text { Concepts" help } \\
\text { students to apply } \\
\text { the theories or } \\
\text { concepts that are } \\
\text { relevant in order } \\
\text { to complete the } \\
\text { assignment. }\end{array}$ \\
\hline $\begin{array}{l}\text { Background } \\
\text { Information }\end{array}$ & Similarity & $\begin{array}{l}\text { "Background } \\
\text { Information" help } \\
\text { students to recall } \\
\text { the concepts they } \\
\text { have learned. }\end{array}$ \\
\hline $\begin{array}{l}\text { What is this } \\
\text { exercise about }\end{array}$ & Tunneling & $\begin{array}{l}\text { "What is this } \\
\text { exercise about ..." }\end{array}$ \\
\hline
\end{tabular}




\begin{tabular}{|c|c|c|}
\hline & & $\begin{array}{l}\text { provides a } \\
\text { comprehensive } \\
\text { overview of the } \\
\text { assignments and } \\
\text { goals to be } \\
\text { achieved, while } \\
\text { giving students the } \\
\text { inspiration of how } \\
\text { to write a program } \\
\text { to solve the task. }\end{array}$ \\
\hline $\begin{array}{l}\text { What should I } \\
\text { know to be } \\
\text { able to do this } \\
\text { exercise.. }\end{array}$ & Similarity & $\begin{array}{l}\text { "What should I } \\
\text { know to be able to } \\
\text { do this } \\
\text { exercise..." } \\
\text { (which refers to } \\
\text { the notification of } \\
\text { the topic or } \\
\text { concept that has } \\
\text { been explained } \\
\text { during lectures) } \\
\text { help students to } \\
\text { relate theory they } \\
\text { have learned in } \\
\text { lectures with } \\
\text { practical } \\
\text { assignments } \\
\text { during } \\
\text { sessions. }\end{array}$ \\
\hline $\begin{array}{l}\text { What will I } \\
\text { learn from this } \\
\text { programming } \\
\text { exercise }\end{array}$ & Tailoring & $\begin{array}{l}\text { "What will I learn } \\
\text { from this } \\
\text { programming } \\
\text { exercise..." (which } \\
\text { refers to the } \\
\text { learning outcomes } \\
\text { to be achieved) } \\
\text { make students } \\
\text { more aware of the } \\
\text { objectives to be } \\
\text { achieved in order } \\
\text { to complete their } \\
\text { assignment. }\end{array}$ \\
\hline $\begin{array}{l}\text { What } \\
\text { resources are } \\
\text { provided.. }\end{array}$ & Tunneling & $\begin{array}{l}\text { "What resources } \\
\text { are provided ..." } \\
\text { refers to a } \\
\text { checklist of the } \\
\text { necessary } \\
\text { supporting } \\
\text { materials to ensure } \\
\text { the smooth } \\
\text { implementation of } \\
\text { the lab practical } \\
\text { session (such as } \\
\text { data, examples of } \\
\text { complete } \\
\text { programs and file } \\
\text { to start writing the } \\
\text { program) guide } \\
\text { students to } \\
\text { complete the }\end{array}$ \\
\hline
\end{tabular}

\begin{tabular}{|c|c|c|}
\hline & & assignments given \\
\hline \multicolumn{3}{|c|}{ Sub section of "What resources are provided ..." } \\
\hline \multirow[t]{6}{*}{ Video } & Tailoring & $\begin{array}{l}\text { Video } \\
\text { presentations } \\
\text { appeal to the } \\
\text { paradigm } \\
\text { today's students } \\
\text { and } \\
\text { persuasive more } \\
\text { attract them in } \\
\text { learning OOP. }\end{array}$ \\
\hline & Reduction & $\begin{array}{l}\text { Video provides a } \\
\text { visual } \\
\text { representation of a } \\
\text { process or form of } \\
\text { output produced } \\
\text { base on the input } \\
\text { data is capable of } \\
\text { delivering an } \\
\text { objective more } \\
\text { clearly and } \\
\text { quickly. }\end{array}$ \\
\hline & Tunneling & $\begin{array}{lr}\text { Guidelines } & \text { and } \\
\text { processes shown } \\
\text { directly through a } \\
\text { video presentation } \\
\text { makes students } \\
\text { more persuaded, } \\
\text { confident } \\
\text { motivated and } \\
\text { complete to their } \\
\text { assignment. }\end{array}$ \\
\hline & $\begin{array}{c}\text { Self- } \\
\text { monitoring }\end{array}$ & $\begin{array}{l}\text { Output that can be } \\
\text { seen through a } \\
\text { video presentation } \\
\text { at each stage can } \\
\text { be used as } \\
\text { reference material } \\
\text { for students to } \\
\text { self-assess their } \\
\text { own progress in } \\
\text { completing the } \\
\text { assignment. }\end{array}$ \\
\hline & Simulation & $\begin{array}{l}\text { The example of } \\
\text { output which } \\
\text { displayed through } \\
\text { a video } \\
\text { presentation } \\
\text { allows students to } \\
\text { immediately see } \\
\text { the relationship } \\
\text { between cause and } \\
\text { effect of a process. }\end{array}$ \\
\hline & Liking & $\begin{array}{l}\text { The video } \\
\text { presentation } \\
\text { showing visually } \\
\text { process is more } \\
\text { attractive and be } \\
\text { more persuasive }\end{array}$ \\
\hline
\end{tabular}




\begin{tabular}{|c|c|c|}
\hline & & $\begin{array}{lr}\text { for } & \text { students } \\
\text { learning } & \text { style } \\
\text { nowadays. } & \\
\end{array}$ \\
\hline & Suggestion & $\begin{array}{l}\text { Techniques or } \\
\text { alternative method } \\
\text { suggested for } \\
\text { solving the } \\
\text { problem through a } \\
\text { video presentation } \\
\text { will have greater } \\
\text { persuasive powers } \\
\text { to engage students } \\
\text { in learning OOP }\end{array}$ \\
\hline & Similarity & $\begin{array}{l}\text { Video } \\
\text { presentations } \\
\text { allow students to } \\
\text { recall about the } \\
\text { concepts that have } \\
\text { been learned and } \\
\text { this makes them } \\
\text { are more readily } \\
\text { persuaded through } \\
\text { systems that } \\
\text { remind them of } \\
\text { themselves in } \\
\text { some meaningful } \\
\text { way. }\end{array}$ \\
\hline & Expertise & $\begin{array}{l}\text { Guided } \\
\text { assignment with } \\
\text { relevant } \\
\text { information that } \\
\text { lead students } \\
\text { through a process } \\
\text { or experience } \\
\text { capable of raising } \\
\text { the level of their } \\
\text { motivation to } \\
\text { continue trying to } \\
\text { solve the tasks } \\
\text { given. }\end{array}$ \\
\hline & Cooperation & $\begin{array}{l}\text { Students are clear } \\
\text { about the input, } \\
\text { process and output } \\
\text { for each stage and } \\
\text { these factors } \\
\text { encourage them to } \\
\text { give full } \\
\text { commitment and } \\
\text { consistency in } \\
\text { completing their } \\
\text { assignment. }\end{array}$ \\
\hline Sample File & Reduction & $\begin{array}{l}\text { The sample file } \\
\text { that can be } \\
\text { executed without } \\
\text { program code } \\
\text { capable of } \\
\text { delivering the } \\
\text { objectives and } \\
\text { process of each }\end{array}$ \\
\hline
\end{tabular}

\begin{tabular}{|c|c|c|}
\hline & & $\begin{array}{l}\text { assignment plainly } \\
\text { and accurately. }\end{array}$ \\
\hline Working File & Tunneling & $\begin{array}{l}\text { Working file that } \\
\text { contains some } \\
\text { specific programs } \\
\text { codes, including } \\
\text { classes available } \\
\text { to write a } \\
\text { complete program } \\
\text { help students to } \\
\text { get the idea more } \\
\text { swiftly (not } \\
\text { "frozen") and } \\
\text { encourage them to } \\
\text { start writing a } \\
\text { program earlier. }\end{array}$ \\
\hline $\begin{array}{l}\text { Class } \\
\text { Documentation }\end{array}$ & Tunneling & $\begin{array}{l}\text { Class } \\
\text { documentation } \\
\text { (which contains } \\
\text { details of classes } \\
\text { and methods) help } \\
\text { students use these } \\
\text { details to create a } \\
\text { class when writing } \\
\text { a program. }\end{array}$ \\
\hline $\begin{array}{l}\text { What do I need } \\
\text { to do.. }\end{array}$ & Reduction & $\begin{array}{l}\text { "What do I need to } \\
\text { do ..." (which } \\
\text { refers to the } \\
\text { process } \\
\text { students need to } \\
\text { do step by step) } \\
\text { help students to } \\
\text { deal with the } \\
\text { complexity of the } \\
\text { assignment and } \\
\text { help students start } \\
\text { writing programs } \\
\text { earlier. }\end{array}$ \\
\hline \multicolumn{3}{|c|}{ Sub section of "What do I need to do ..." } \\
\hline $\begin{array}{l}\text { Task } \\
\text { description }\end{array}$ & Tunneling & $\begin{array}{l}\text { Task description } \\
\text { refers to the } \\
\text { specific } \\
\text { instructions for the } \\
\text { small part of the } \\
\text { assignment at } \\
\text { every stage } \\
\text { facilitate students } \\
\text { to complete their } \\
\text { assignment. }\end{array}$ \\
\hline $\begin{array}{l}\text { At the end of } \\
\text { this stage, you } \\
\text { should have } \\
\text { produced a } \\
\text { program } \\
\text { which... }\end{array}$ & Tunneling & $\begin{array}{l}\text { "At the end of this } \\
\text { stage, you should } \\
\text { have produced a } \\
\text { program which..." } \\
\text { (referring to the } \\
\text { objectives, } \\
\text { outputs, and } \\
\text { features that meet } \\
\text { the requirements } \\
\text { of the question) }\end{array}$ \\
\hline
\end{tabular}




\begin{tabular}{|c|c|c|}
\hline & & $\begin{array}{l}\text { informed in detail } \\
\text { so that students } \\
\text { know what to do } \\
\text { undoubtedly at } \\
\text { every stage. }\end{array}$ \\
\hline $\begin{array}{l}\text { What is this } \\
\text { stage about... }\end{array}$ & Expertise & $\begin{array}{l}\text { "What is this stage } \\
\text { about..." provide a } \\
\text { specific } \\
\text { description of the } \\
\text { objectives to be } \\
\text { achieved at each } \\
\text { stage give students } \\
\text { inspiration on how } \\
\text { to write accurate } \\
\text { program } \\
\text { completing the } \\
\text { assignments }\end{array}$ \\
\hline Procedure & Tunneling & $\begin{array}{l}\text { The procedure } \\
\text { refers to the } \\
\text { details of the } \\
\text { process containing } \\
\text { supporting } \\
\text { material such as } \\
\text { video, details } \\
\text { guidelines, } \\
\text { reinforcement } \\
\text { questions and } \\
\text { suggestions which } \\
\text { should be done in } \\
\text { step by step makes } \\
\text { the objective of } \\
\text { each level can be } \\
\text { achieved more } \\
\text { easily. }\end{array}$ \\
\hline $\begin{array}{l}\text { Reinforcement } \\
\text { Question }\end{array}$ & Tailoring & $\begin{array}{l}\text { Reinforcement } \\
\text { question refers to } \\
\text { the theoretical and } \\
\text { practical questions } \\
\text { posed in } \\
\text { association with } \\
\text { the procedures } \\
\text { undertaken to } \\
\text { encourage } \\
\text { students think } \\
\text { critically } \\
\text { connecting } \\
\text { programming } \\
\text { concepts that they } \\
\text { have learned while } \\
\text { performing the lab } \\
\text { assignments. }\end{array}$ \\
\hline
\end{tabular}

\section{The New Structure of OOP Lab Assignments}

Object Oriented Programming course is a compulsory course for second year students of the Faculty of Information Science and Technology,
Universiti Kebangsaan Malaysia (UKM). This course introduces Object Oriented Programming paradigm in problem solving using Java programming language. Before taking this course, the students went through two programming courses in the first year; Programming and Data Structures. Both of these courses used $\mathrm{C}++$ as the programming language.

Object-Oriented Programming course teaching component consists of lectures, tutorials, lab assignments and projects. Lectures are to deliver course materials and tutorials are for discussing problems related theories and concepts. In lab sessions, students were given problem-based questions and required to solve the problem by writing programs using object oriented paradigm. For the project, students were required to design and develop a mid-sized software in groups based on the problems presented. Acquired skills in problem solving lab sessions will help students to produce good quality project

The new structure of OOP lab assignments for this course was introduced in semester 1 , session 2013/2014 year.

\section{Findings}

A total of 190 out of the 202 students who attended the seven lab sessions (the full version of this assignments can be retrieve through http://www.ftsm.ukm.my/java) during a semester that applies the principles of persuasive technology for Object Oriented Programming courses in Semester 1, 2013/2014 were the responding to the survey conducted. A range of view collected covers the assignment structure, supporting material provided, level of acceptance and their understanding about the assignment. On average, $80 \%$ of students agreed that each section of the lab assignment is beneficial to them as specified by the relevant selected principles of persuasive technology. The results showed that the framework constructed can serve as a guide for designing persuasive OOP lab assignments that once could change the attitude of students, especially average category of students to becomes more positive, motivated and responsible in completing OOP lab assignments.

A supporting material that have great persuasive impact on students is the video element. It is a learning resource that is very amazing and able to convey or illustrate a process visibly. This study shows the video has all (ten) principles of persuasive technology which were adopted in the new structure of OOP lab assignment. While the video is only a side in the overall structure of the lab assignment, students responded very positively to it. Video is an important element in helping students acquire information compared to text-based materials and static images only. Below is a synopsis of 
implications and behavior changes of the students towards the OOP lab assignments given based on persuasive technology principles:

Table 6. Persuasive Principles and Implication

\begin{tabular}{|c|c|}
\hline \multicolumn{2}{|r|}{ Primary Task Support } \\
\hline Principle & Implication \\
\hline Tailoring & $\begin{array}{l}\text { The approach of this lab OOP } \\
\text { assignment initiate students working } \\
\text { early and those who do so are much } \\
\text { more likely to complete the } \\
\text { assignment they have already in } \\
\text { progress. They have a clearer } \\
\text { interpretation of what they are doing } \\
\text { so it is easy to start and not 'freeze' } \\
\text { at the assignment }\end{array}$ \\
\hline Reduction & $\begin{array}{l}\text { Upon answering the given lab } \\
\text { assignment, most students thought } \\
\text { that programming subject is not very } \\
\text { difficult to understand. It is } \\
\text { depending on how questions are } \\
\text { asked in order to help them } \\
\text { understand and assimilate the object } \\
\text { oriented concepts being learned. }\end{array}$ \\
\hline Tunnelling & $\begin{array}{l}\text { The guided step by step assignment } \\
\text { structures provide a more seamless } \\
\text { learning environment where students } \\
\text { are not left behind in the lab session } \\
\text { although there are students who are } \\
\text { late. }\end{array}$ \\
\hline $\begin{array}{l}\text { Self- } \\
\text { monitoring }\end{array}$ & $\begin{array}{l}\text { The students become more } \\
\text { courageous to interact with } \\
\text { instructors and know specifically } \\
\text { what to ask of a given assignment. } \\
\text { They used the video presentation as a } \\
\text { point of reference in writing program } \\
\text { and were excited to show the results } \\
\text { that have been successfully produced } \\
\text { for each stage. }\end{array}$ \\
\hline Simulation & $\begin{array}{l}\text { The short completion period of each } \\
\text { stage formulated students to feel a } \\
\text { sense of incremental achievement. It } \\
\text { can enhance their confidence and } \\
\text { they believe in their capabilities and } \\
\text { abilities to complete the tasks. It can } \\
\text { prevent boredom and pressure when } \\
\text { dealing with syntax errors that have } \\
\text { to be addressed if writing extensive } \\
\text { code program at once. }\end{array}$ \\
\hline & Dialogue Support \\
\hline Principle & Implication \\
\hline Liking & $\begin{array}{l}\text { The learning style of today's students } \\
\text { are visual in nature, filled with } \\
\text { animated elements and all the } \\
\text { information at their fingertips. Video } \\
\text { that appeals to their paradigm } \\
\text { inserted in a lab assignment cause } \\
\text { surge of motivation in learning a }\end{array}$ \\
\hline
\end{tabular}

\begin{tabular}{|c|l|}
\hline Suggestion & $\begin{array}{l}\text { programming course. } \\
\text { Techniques or alternative method } \\
\text { suggested for solving the problem } \\
\text { successfully make students think } \\
\text { further to produce more quality and } \\
\text { efficient programming code. }\end{array}$ \\
\hline Similarity & $\begin{array}{l}\text { The notification of the topic or } \\
\text { concept include in the assignment } \\
\text { help students to recall and relate } \\
\text { theory they have learned in lectures } \\
\text { with practical assignments during lab } \\
\text { sessions. }\end{array}$ \\
\hline System Credibility Support \\
\hline Expertise & $\begin{array}{l}\text { The details and information of OOP } \\
\text { lab assignments were very effective, } \\
\text { especially in introducing students } \\
\text { (average category) to the new } \\
\text { concepts of OOP. }\end{array}$ \\
\hline Principle & \multicolumn{1}{|c|}{ Social Support } \\
\hline Cooperation & $\begin{array}{l}\text { Since the OOP lab assignments was } \\
\text { designed especially for targeted } \\
\text { group, average category of students, } \\
\text { opinion from the excellent category } \\
\text { of students also were considered. } \\
\text { Quite a few of them point out that } \\
\text { they prefer the open questions which } \\
\text { can unleash their creativity and test } \\
\text { their ability to solve the OOP task. } \\
\text { However, there is not a problem for } \\
\text { them to accept the form of these } \\
\text { assignments. They get the job done } \\
\text { faster than the average category of } \\
\text { students. If the average category of } \\
\text { students at the early stage, they can } \\
\text { reach a higher stage and utilized two } \\
\text { hours time during the lab session. }\end{array}$ \\
\hline
\end{tabular}

\section{Conclusion}

Students appreciate the assignments that are simple, easy to tackle and contain visual elements that can give ideas and a clear view of the assignment. This assignment structures provide a more seamless learning environment for them. The short completion period of each stage formulated students to feel a sense of incremental achievement. Supporting materials such as videos are important learning resources that facilitate students to get knowledge more powerfully and natural compared to text-based learning resources. The idea is that the more interested students are in the assignment they attempt to complete, the more time they will spend exploring the programming concepts that the assignment is projected to teach and they can produce quality coding. Maintaining students' 
motivation to persist in learning is both interesting and rewarding especially in OOP environment

\section{References}

[1] A. Eckerdal and M. Thune, Novice Java Programmers' Conceptions of "Object" and "Class", and Variation Theory. In Proceedings of the 10th annual SIGCSE conference on Innovation and Technology in Computer Science Education (ITiCSE '05), 2005, pp. 89-93.

[2] Cialdini, R. B., Influence: Science And Practice, Boston: Allyn \& Bacon, 2001.

[3] Fogg, B. J., Persuasive Technology: Using Computers to Change What We Think and Do. Morgan Kaufmann, 2003.

[4] H. Oinas-Kukkonen and M. Harjumaa, Persuasive Systems Design: Key Issues, Process Model, and System Features. Communications of the Association for Information Systems 24(28), 2009, pp.485-500.

[5] J. Mintz, and M. Aagaard, The Application of Persuasive Technology to Educational Settings, Educational Technology Research and Development 60(3), 2012, pp. 483-499.

[6] K. Kellermann and T. Cole, Classifying Compliance Gaining Messages: Taxonomic Disorder and Strategic Confusion. Communication Theory 4(1), 1994, pp. 3-60.

[7] M. Feldstein, and D. Kruse, The Power of Multimedia Games. Training Development 52(2), 1998, pp. 62-63.

[8] M.L Tombari, S.J Fitzpatrick and W. Childress, Using Computers as Contingency Managers in Self-monitoring Interventions: A case study. Computers in Human Behavior, 1985, pp.75-82.

[9] P.A. Alexander, H. Fives, M.M. Buehl, and J. Mulhern, Teaching as persuasion, Teaching and Teacher Education 18 (7), 2002, pp. 795- 813.

[10] R.B. Cialdini, The Science of Persuasion. Scientific American Mind 284, 2004, pp. 76-84.

[11] R.E. Petty, and J.T Cacioppo, The Effects of Involvement on Responses to Argument Quantity and Quality: Central and Peripheral Routes to Persuasion, Journal of Personality and Social Psychology 46, 1984 pp. 69-81.

[12] S. Worchel, J. Cooper, G.R Goethals, and J. M Olson, J. M. 2000. Prejudice and Stereotypes, Social Psychology, Ch 7, Wadsworth: Belmont, CA, 2000, pp. 192-223. 